\title{
Genetic Connectivity Between Papaya Ringspot Virus Genomes from Papua New Guinea and Northern Australia, and New Recombination Insights
}

\author{
Solomon Maina, ${ }^{1,2,3}$ Martin J. Barbetti, ${ }^{1,2,3}$ Owain R. Edwards, ${ }^{3,4}$ David Minemba, ${ }^{1,5}$ Michael W. Areke, ${ }^{6}$ and \\ Roger A. C. Jones ${ }^{2,3,7, \dagger}$ \\ ${ }^{1}$ School of Agriculture and Environment, Faculty of Science, The University of Western Australia, Crawley, WA, Australia; \\ ${ }^{2}$ UWA Institute of Agriculture, Faculty of Science, The University of Western Australia, Crawley, WA, Australia; ${ }^{3}$ Cooperative \\ Research Centre for Plant Biosecurity, Canberra, ACT, Australia; ${ }^{4}$ CSIRO Land and Water, Floreat Park, WA6014, Australia; \\ ${ }^{5}$ The National Agriculture Research Institute, P.O. Box 4415, Lae, Morobe Province, Papua New Guinea; ${ }^{6}$ National Agriculture \\ Quarantine and Inspection Authority, P.O. Box 741, Port Moresby, National Capital District, Papua New Guinea; and ${ }^{7}$ Depart- \\ ment of Primary Industries and Rural Development Food Western Australia, South Perth, WA, Australia
}

\begin{abstract}
Isolates of papaya ringspot virus (PRSV) were obtained from plants of pumpkin (Cucurbita spp.) or cucumber (Cucumis sativus) showing mosaic symptoms growing at Zage in Goroka District in the Eastern Highland Province of Papua New Guinea (PNG) or Bagl in the Mount Hagen District, Western Highlands Province. The samples were sent to Australia on FTA cards where they were subjected to High Throughput Sequencing (HTS). When the coding regions of the six new PRSV genomic sequences obtained via HTS were compared with those of 54 other complete PRSV sequences from other parts of the world, all six grouped together with the 12 northern Australian sequences within major phylogroup B minor phylogroup I, the Australian sequences coming from three widely dispersed locations spanning the north of the continent. Notably, none of the PNG isolates grouped with genomic sequences from the nearby country of East Timor in phylogroup A. The closest genetic match between Australian and PNG sequences was a nucleotide (nt) sequence identity of $96.9 \%$, whereas between PNG and East Timorese isolates it was only $83.1 \%$. These phylogenetic and nt identity findings demonstrate genetic connectivity between PRSV populations from

PNG and Australia. Recombination analysis of the 60 PRSV sequences available revealed evidence of 26 recombination events within 18 isolates, only four of which were within major phylogroup B and none of which were from PNG or Australia. Within the recombinant genomes, the $\mathrm{P} 1, \mathrm{Cl}$, NIa-Pro, NIb, 6K2, and 5'UTR regions contained the highest numbers of recombination breakpoints. After removal of nonrecombinant sequences, four minor phylogroups were lost (IV, VII, VIII, XV), only one of which was in phylogroup B. When genome regions from which recombinationally derived tracts of sequence were removed from recombinants prior to alignment with nonrecombinant genomes, seven previous minor phylogroups within major phylogroup $\mathrm{A}$, and two within major phylogroup B, merged either partially or entirely forming four merged minor phylogroups. The genetic connectivity between PNG and northern Australian isolates and absence of detectable recombination within either group suggests that PRSV isolates from East Timor, rather than PNG, might pose a biosecurity threat to northern Australian agriculture should they prove more virulent than those already present.
\end{abstract}

In the world's tropical and subtropical regions, papaya ringspot virus (PRSV; family Potyviridae; genus Potyvirus) causes serious diseases of cucurbit and papaya (Carica papaya) crops. It has flexuous filamentous particles 760-800 nm long (Purcifull et al. 1984), and is transmitted nonpersistently by several aphid species (Purcifull et al. 1984). Seed transmission occurs occasionally (Bayot et al. 1990). Although pathotype PRSV-P infects papaya and cucurbits, pathotype PRSV-W infects cucurbits but not papaya (Purcifull et al. 1984). It seems likely that PRSV-P outbreaks have evolved independently from PRSV-W infections in different regions of the world (Bateson et al. 1994, 2002; Desbiez et al. 2017; Gibbs et al. 2008a,b). Cucurbitaceous weeds are natural reservoirs for spread of both PRSV biotypes to crops (Chin et al. 2007; Magdalita et al. 1990; Mansilla et al. 2013; Zitter et al. 1996). PRSV-P and PRSV-W isolates cause leaf and fruit symptoms of mottle, ringspots, and deformation, and

${ }^{\dagger}$ Corresponding author: R. A. C. Jones; E-mail: roger.jones@uwa.edu.au

Funding: The Cooperative Research Centre for Plant Biosecurity (PBCRC61056) and UWA provided a Scholarship for international Research Fees (SIRF). Both organizations and the Commonwealth Scientific and Industrial Research Organisation (CSIRO) provided operating funds. UWA provided laboratory facilities for this research.

*The $\boldsymbol{e}$-Xtra logo stands for "electronic extra" and indicates that two supplementary tables are published online.

Accepted for publication 11 October 2018.

@ 2019 The American Phytopathological Society overall plant stunting in their respective crop hosts; both greatly decrease fruit yield and marketability (Purcifull et al. 1984; Zitter et al. 1996). PRSV is thought to have spread several times from the Indian subcontinent to the rest of the world and belongs to a cluster of viruses with similar biological and molecular properties. PRSV-W apparently came first, while PRSV-P subsequently evolved from it (Bateson et al. 2002; Desbiez et al. 2017; Gibbs et al. 2008a; Olarte Castillo et al. 2011).

Within Australia, PRSV-P infects papaya crops growing in the Northern Territory (NT), which has a tropical climate, and tropical and subtropical northeast Queensland (QLD) (Bateson and Dale 1992; Bateson et al. 1994; Thomas and Dodman 1993). The distribution of cucurbit crop infection with PRSV-W extends from Cairns in northeast QLD westward to crops growing at Darwin and Katherine in the NT, and Kununurra and Broome in the East and West Kimberley regions of Western Australia (WA), respectively; and southward along the Pacific coastline to Grafton in subtropical northern New South Wales (NSW) (Büchen-Osmond et al. 1988; Coutts and Jones 2005; Greber 1969; Herrington 1987; Jones 1996; Maina et al. 2017b). In neighboring countries to the north of Australia, PRSV occurs in Indonesia, East Timor, and Papua New Guinea (PNG) (CABI/ EPPO 2013; Davis et al. 2002; Maina et al. 2017b; Somowiyarjo 1993). PRSV-W has been found in East Timor, PNG, and the Indonesian province of Papua, and PRSV-P in the rest of Indonesia apart from Papua province (Davis et al. 2002; Maina et al. 2017b; Rai et al. 2015).

Agriculture commenced in PNG around 6,000 years ago (Denham et al. 2003), but only 230 years ago in Australia, reaching some of the continent's remote regions only 60 years ago. Consequently, Australia still lacks many viruses or their virulent biological strains that 
induce serious crop diseases in other parts of the world, and other crop viruses only arrived recently. Most new introductions arise from international trade in plants and plant products arriving via inadvertent importation of infected vegetative propagules or seeds (Gibbs et al. 2008b; Jones 2009). Introductions could also result from migrating birds carrying virus-infected seeds in their guts, or from viruliferous insect vectors carried by monsoonal winds from Australia's northern neighbors. After analysis of viral nucleotide (nt) sequences from around Australia, evidence such spread could have occurred was provided for the nonpersistently aphid-borne viruses zucchini yellow mosaic virus (ZYMV) and sweet potato feathery mottle virus (SPFMV), both from genus Potyvirus, family Potyviridae. ZYMV isolates from Kununurra demonstrated genetic connectivity with isolates from East Timor (Coutts et al. 2011a,b; Maina et al. 2017a), as did SPFMV isolates from Cairns and Kununurra (Maina et al. 2018a, c). By contrast, no such genetic connectivity was found between isolates from East Timor and northern Australia for PRSV or for a further potyvirus, sweet potato virus C (Maina et al. 2018a,c). 'Genetic connectivity' is a biosecurity term used when genetically similar nucleic acid sequences are found among populations derived from different countries.

The current study obtained the first complete genomic PRSV sequences from PNG from six different infected plants. To investigate whether genetic connectivity exists between PRSV-W populations from PNG, Australia, and East Timor, we compared the six new PNG genomes with the 17 complete genomic PRSV sequences obtained previously from northern Australia and East Timor, and the 37 others retrieved from GenBank. The objective was to (i) test the hypothesis that "plant viral pathogens of economically important crops are spreading into tropical northern Australia from its northern neighbours" (Maina et al. 2016a,b,c,d,e,f, 2017a,b,c,d,e,f, 2018a,b,c), and (ii) improve current understanding of the phylogenetics of, and provide new recombination insights for, this virus by using the most up-to-date recombination analysis program.

\section{Materials and Methods}

Isolate collection. In October 2016, 23 leaf samples (1/plant) were collected from cucumber and pumpkin plants with virus-like symptoms growing in multiple smallholder farms at Bagl, Kongop, Lilinga, and Zage in the highlands of PNG (Fig. 1, Table 1). Each sample was blotted onto FTA Classic Cards (GE Healthcare, United Kingdom) as described by Ndunguru et al. (2005), then air-dried for $10 \mathrm{~min}$ at room temperature before packaging for transfer to Australia.

RNA extraction and RT-PCR. The 23 PNG samples blotted onto FTA cards were sampled by punching up discs approximately $2 \mathrm{~mm}$ diameter from each blotted sample. The 20 discs from each blotted sample were pooled and used to extract total RNA using a ZR Plant RNA MiniPrep kit (Zymo Research, Irvine, CA) following manufacturer's instructions. Crude RNA was treated and quality control undertaken as described previously (Guerret et al. 2017; Maina and Jones 2017; Maina et al. 2016a,b,c,d,e,f, 2017a,b,c,d,e,f) and RTPCR using generic potyvirus LegPotyF and LegPotyR primers as described by Webster (2008). Thirteen of the 23 PNG samples were potyvirus positive.

High throughput sequencing (HTS). RNASeq libraries were prepared from the 13 potyvirus positive sample extracts using $1 \mu \mathrm{g}$ of total RNA with a TruSeq stranded Total RNA Sample Preparation kit incorporating Ribozero Plant (Illumina, San Diego, CA) as described previously (Guerret et al. 2017; Maina and Jones 2017; Maina et al. 2016a,b,c,d,e,f, 2017a,b,c,d,e,f). The final size and concentration of each library were verified using Qubit and D1000 ScreenTape (TapeStation 2200, Agilent Technologies). The stranded

A

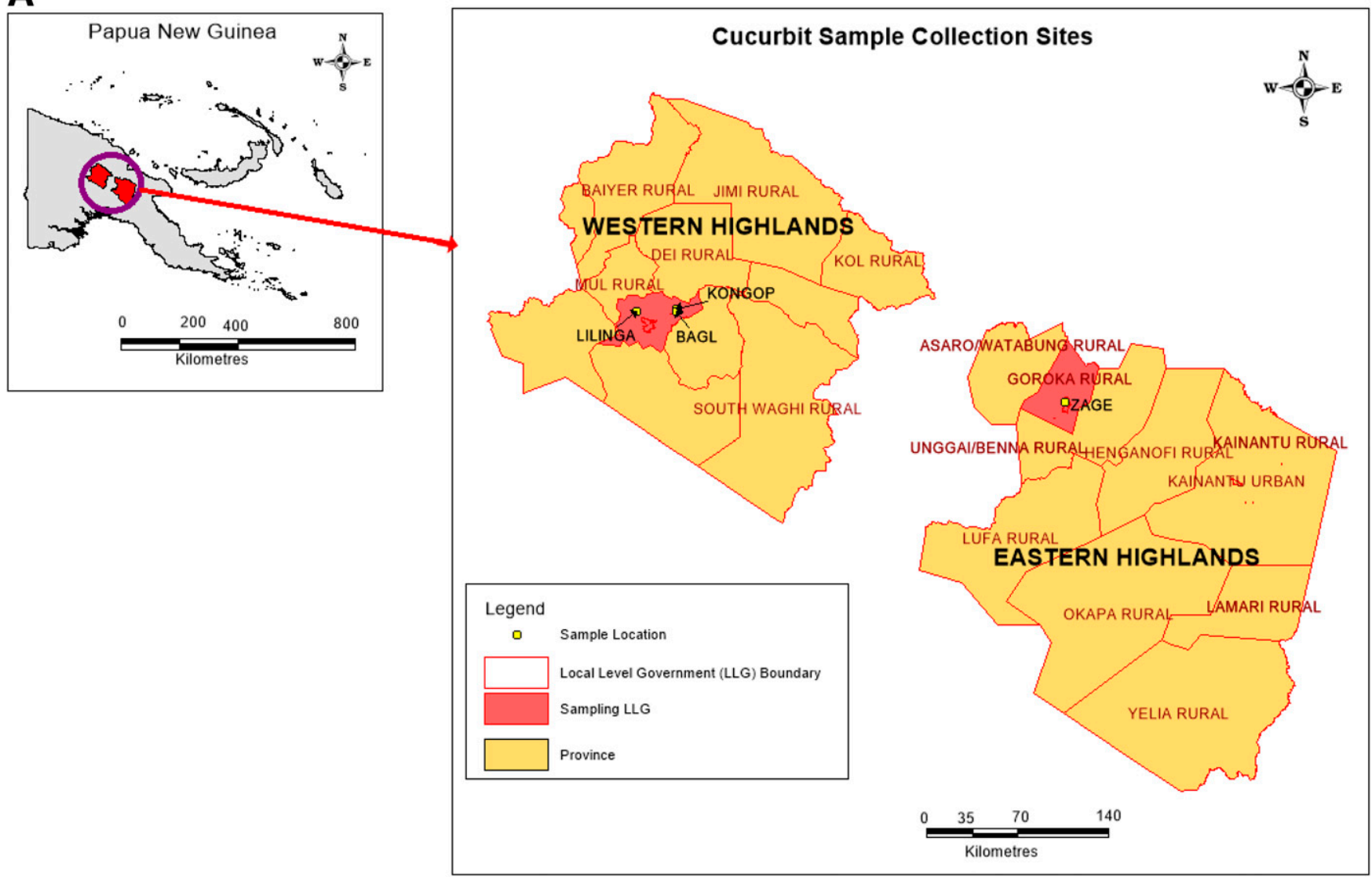

(Continued)

Fig. 1. (A) Map of Papua New Guinea (PNG) showing locations in the Western and Eastern Highlands where leaf samples infected with papaya ringspot virus (PRSV) were collected from cucurbit crops. The district in which Bagl, Kongop, and Lilinga are located is Mount Hagen (not shown on map) in the Western Highlands Province. (B) Cucumber plant with mosaic symptoms growing in the field in Zage, Goroka District, Eastern Highlands Province, PNG. 
libraries were sent to Macrogen Inc., South Korea, where they were subjected to HiSeq 2500 using a Truseq SBS KIT v4 (Illumina) with 151 cycles to generate paired-end reads in a multiplex of 24 samples in one lane.

Sequence analysis. After sequencing, RNASeq reads were subjected to analysis with CLC Genomics Workbench 6.5 (CLCGW) (CLC bio, Qiagen, Redwood City, CA) for quality control followed by subsequent de novo assemblies as described previously (Kehoe et al. 2014a; Maina and Jones 2017; Maina et al. 2016a,b,c,d, e,f, 2017a,b,c,d,e,f). All the contigs were subjected to a CLCGW Blastn search tool and subsequently to PASC sequence comparisons (Altschul et al. 1990; Bao et al. 2014). All contigs with plant virus matches were used for further analysis. Consensus sequence integrity was investigated and its full length polyprotein used with the contig of interest from CLCGW. Then, both were aligned in Geneious using MAFFT (Katoh et al. 2002) to create a final sequence. Open reading frames (ORFs) were predicted and annotations made using Geneious. Screening for vector contamination was undertaken using the NCBI vector screen tool (https://www.ncbi.nlm.nih.gov/tools/ vecscreen). Finalized sequences were designated as complete coding sequences based on comparison with the reference sequences used in the mapping process, or nearly complete if some of the $5^{\prime}$ or 3' UTR was missing but the complete polyprotein coding regions were intact. Percent nt identity scores between complete genomes were calculated using the pairwise function in Geneious with the number of differences model (Kearse et al. 2012), and a matrix of nt identities produced using Sequence Demarcation tool v1 (Muhire et al. 2014). Six sequences of PRSV and 10 of ZYMV were obtained, and three samples $(8 \mathrm{~A}, 17 \mathrm{~B}, 22 \mathrm{~A})$ of the 13 infected samples contained both viruses. The six complete genomic PRSV sequences, including ones from the three samples which contained both viruses, were deposited in GenBank under the accession numbers MH404259 - MH404264.

Recombination detection. The complete coding sequences of the six new PRSV genomes from PNG and 54 others reported previously retrieved from GenBank (Table 1) were assessed for evidence of recombination. RDP version 5.2 (Martin et al. 2015) was used to detect putative recombination break points between these 60 sequences. Any detected recombination signals that were flagged by RDP5.2 as potentially arising through evolutionary processes other than recombination were disregarded. Default parameters were used for the seven recombination detection methods implemented using

Fig. 1. (Continued from previous page)

B

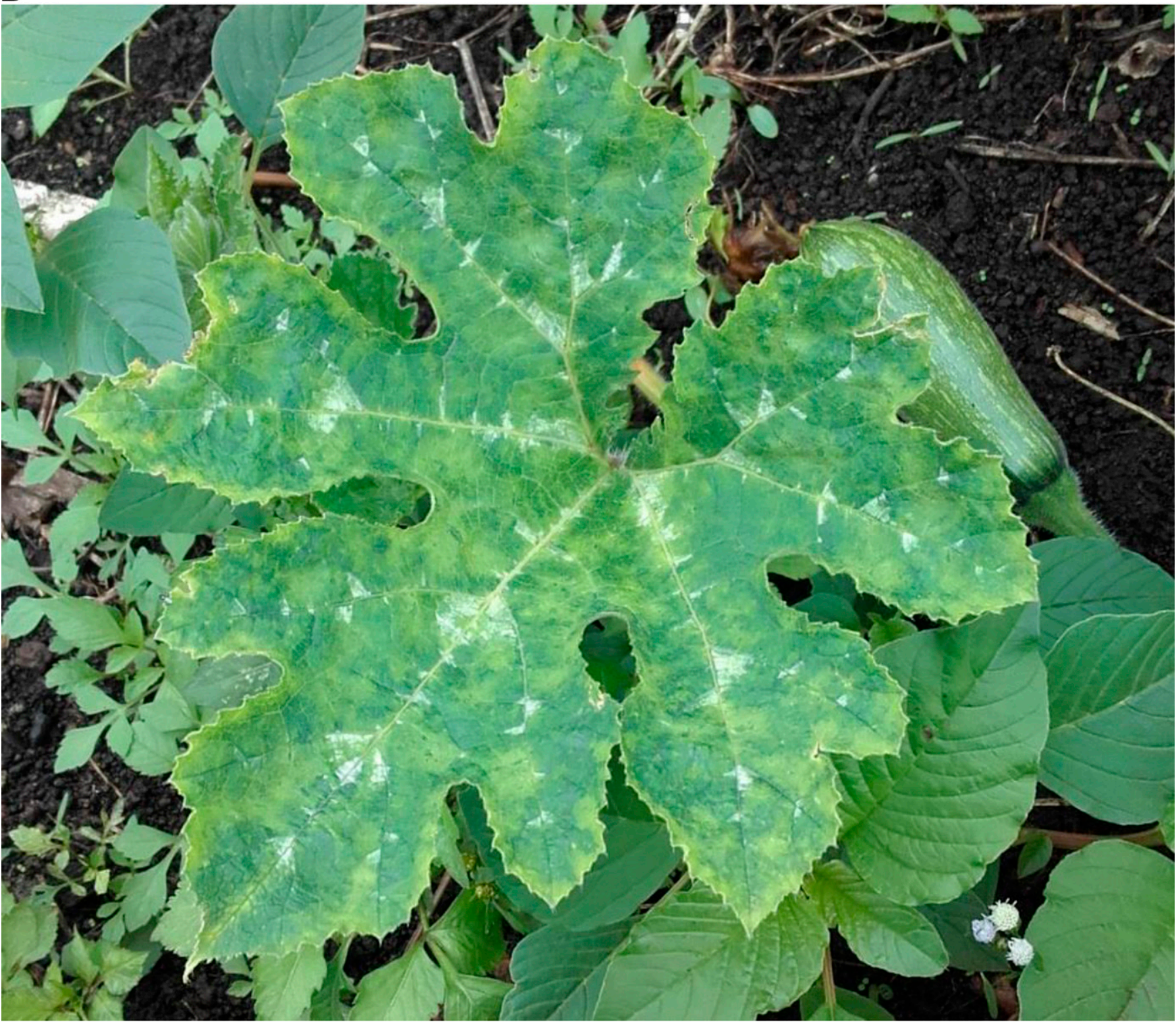


RDP5.2: RDP (Martin et al. 2005), GENECONV (Padidam et al. 1999), Bootscan (Martin et al. 2005), MaxChi (Smith 1992), Chimaera (Posada and Crandall 2001), SiScan (Gibbs et al. 2000), and Topal (McGuire and Wright 2000). Only potential recombination events with an associated Bonferroni-corrected $P$ value $<0.05$ for four or more recombination detection methods were considered credible evidence of recombination (Ohshima et al. 2002). The BURT method of Martin et al. (2015) was used to infer the locations and $95 \%$ confidence intervals of break point locations. Recombination breakpoint locations and the origins of regions of sequence that had potentially been transferred during recombination were verified individually using the phylogenetic tools implemented in RDP5.2. A maximum likelihood phylogenetic tree accounting for recombination was constructed using RAxML (Martin et al. 2015) with the GTRCAT model and 100 bootstrap replicates.

Phylogenetics and nucleotide identities. Using Clustal W in MEGA 7.0.14 (Kumar et al. 2016; Larkin et al. 2007), the coding regions of the six new PRSV sequences were aligned with those of 54 other complete PRSV genome sequences retrieved from GenBank (Table 1). An additional alignment included only the nonrecombinant genome sequences, making a total of six new and 36 other sequences. Some other sequences were removed due to poor editing, redundancy, or because they were incomplete. Supplementary Table $\mathrm{S} 1$ provides details of all the complete PRSV sequences from GenBank and to which biotypes each belongs. Phylogenetic analysis was used to compare the coding regions of (i) all six new complete PRSV genomes from PNG along with the 17 sequenced previously from Australia and East Timor, with 37 other complete PRSV genomes retrieved from GenBank, and (ii) all nonrecombinant sequences which consisted of the six new ones from PNG, 12 from Australia, three from East Timor, and 21 from GenBank. Maximum Likelihood phylogenetic trees were constructed using the TamuraNei model (found to be the best fitting of eight tested models in MEGA 7.0.14; Kumar et al. 2016), with bootstrap support values of 1,000 . The codon positions included were first+second+third+ noncoding. The trees were rooted with zucchini tigre mosaic virus
(ZTMV) E11045 (KC345608). The within-virus species phylogroup classification system adopted uses a neutral nomenclature system involving letters of the alphabet and Latinized numerals that avoid potentially misleading names based on biology or geography (Jones and Kehoe 2016). This was partially adopted for PRSV previously by using Latinized numerals to name its minor phylogroups but without adopting letters of the alphabet for its two major phylogroups, retaining geographical names instead (Maina et al. 2017b).

\section{Results}

Natural infection. The six PRSV genomes were from multiple smallholder farms in the Western and Eastern Highlands of PNG (Fig. 1A; Table 1). Five came from cucurbit crop plants showing mosaic symptoms (Fig. 1B) growing in Zage Village in the Goroka District, Eastern Highlands Province of PNG. One of these samples was from cucumber (sample 17B) and 4 from pumpkin (8A, 12B, 18B, 22A). The remaining sample came from a pumpkin plant with mosaic symptoms growing in Bagl Village in the Mount Hagen District, Western Highlands Province (16A). The numbers of samples with PRSV from each location were: 5/12 from Zage, 1/2 from Bagl, 0/7 from Kongop, and 0/2 from Lilinga (Lilinga and Kongop are in Mount Hagen District).

High throughput sequence data. RNA-Seq analysis of the six PNG sample extracts with PRSV revealed 16,422,606-27,363,898 raw paired end reads which were subsequently reduced to 16,417,404-27,360,046 after quality control (Supplementary Table S2). Using CLCGW de novo assembly, the numbers of contigs produced were 329-2,696 and the number of reads mapping to the contig of interest were 185,217-2,227,120. The contigs of interest were more than $10,310 \mathrm{nt}$ in length with average coverage of 6,293-21,568. Final sequence lengths consisted of the consensus of the contig from CLCGW with the consensus from Geneious, and were 10,317-10,393 nt. All six samples yielded a complete genomic sequence of PRSV. The ZYMV sequences also present in samples $8 \mathrm{~A}, 17 \mathrm{~B}$, and $22 \mathrm{~A}$ will be reported elsewhere.

Table 1. Details of the Papaya ringspot virus isolates from Papua New Guinea, East Timor, and Australia

\begin{tabular}{|c|c|c|c|c|c|c|}
\hline Isolate & Host & Symptoms & Geographical origin & $\begin{array}{l}\text { Year of } \\
\text { isolation }\end{array}$ & $\begin{array}{l}\text { Accession } \\
\text { no. }\end{array}$ & Isolate origin \\
\hline $8 \mathrm{~A}^{\mathrm{a}}$ & Pumpkin & Mosaic & Zage, Goroka District, Papua New Guinea & 2016 & MH404259 & This study \\
\hline $12 \mathrm{~B}$ & Pumpkin & Mosaic & Zage, Goroka District, Papua New Guinea & 2016 & MH404260 & This study \\
\hline $16 \mathrm{~A}$ & Pumpkin & Mosaic & $\begin{array}{l}\text { Bagl, Mt Hagen District, Papua New } \\
\text { Guinea }\end{array}$ & 2016 & MH404261 & This study \\
\hline $17 \mathrm{~B}^{\mathrm{a}}$ & Cucumber & Mosaic & Zage, Goroka District, Papua New Guinea & 2016 & MH404262 & This study \\
\hline 18B & Pumpkin & Mosaic & Zage, Goroka, District, Papua New Guinea & 2016 & MH404263 & This study \\
\hline $22 \mathrm{~A}^{\mathrm{a}}$ & Pumpkin & Mosaic & Zage, Goroka District, Papua New Guinea & 2016 & MH404264 & This study \\
\hline TM3 & Pumpkin & Virus-like & Dili, East Timor & 2015 & KX655865 & Maina et al. $2017 b$ \\
\hline TM4 & Pumpkin & Virus-like & Dili, East Timor & 2015 & KX655864 & Maina et al. $2017 b$ \\
\hline TM29 & Watermelon & Virus-like & Dili, East Timor & 2015 & KX655863 & Maina et al. $2017 b$ \\
\hline TM32 & Pumpkin & Virus-like & Dili, East Timor & 2015 & KX998707 & Maina et al. 2017b \\
\hline TM50 & Cucumber & Virus-like & Aileu, East Timor & 2015 & KX655874 & Maina et al. $2017 b$ \\
\hline B9 & Pumpkin & Mosaic & Broome, WA ${ }^{b}$, Australia & 2004 & KX655867 & $\begin{array}{l}\text { Coutts and Jones } \\
2005\end{array}$ \\
\hline $23 \mathrm{C}$ & Watermelon & Mosaic & Broome, WA, Australia & 2015 & KX655861 & Maina et al. 2017b \\
\hline $43 \mathrm{C}$ & Kent pumpkin & Mosaic, palor, stunting & Broome, WA, Australia & 2015 & KX655869 & Maina et al. 2017b \\
\hline $45 \mathrm{C}$ & Kent, pumpkin & Mosaic, leaf deformation & Broome, WA, Australia & 2015 & KX655870 & Maina et al. $2017 b$ \\
\hline $51 \mathrm{C}$ & Kent, pumpkin & Mosaic, leaf deformation & Broome, WA, Australia & 2015 & KX655862 & Maina et al. 2017b \\
\hline $53 \mathrm{C}$ & $\begin{array}{c}\text { Halloween } \\
\text { pumpkin }\end{array}$ & Leaf deformation & Broome, WA, Australia & 2015 & KX655866 & Maina et al. $2017 b$ \\
\hline $54 \mathrm{C}$ & Honeydew melon & Mosaic & Broome, WA, Australia & 2015 & KX998708 & Maina et al. 2017b \\
\hline $55 \mathrm{C}$ & Watermelon & Mosaic, leaf deformation & Broome, WA, Australia & 2015 & KX655868 & Maina et al. $2017 b$ \\
\hline $4 \mathrm{NT}$ & Unknown & Unknown & NT, Australia & 2014 & KX655860 & Maina et al. $2017 b$ \\
\hline $24 \mathrm{NT}$ & Watermelon & Mosaic & Darwin, NT, Australia & 2014 & KX655871 & Maina et al. 2017b \\
\hline $38 \mathrm{NT}$ & Honeydew melon & $\begin{array}{l}\text { Mosaic and leaf } \\
\text { distortion }\end{array}$ & Darwin, NT, Australia & 2011 & KX655872 & Maina et al. 2017b \\
\hline $16 \mathrm{R}$ & Watermelon & Mosaic & Ayr, QLD, Australia & 2011 & KX655873 & Maina et al. $2017 b$ \\
\hline
\end{tabular}

${ }^{a}$ From samples that contained mixed infection with ZYMV.

b WA = Western Australia, Mt = Mount, NT = Northern Territory, QLD = Queensland. 
Phylogenetic relationships. When phylogenetic analyses were used to compare the complete genome coding regions of the six new genomic PRSV sequences from PNG, 17 previously sequenced from Australia and East Timor, and the 37 others from GenBank, this revealed the predicted major phylogroups $\mathrm{A}$ and $\mathrm{B}$, formerly named
'Asian' and 'Five continents', respectively (Fig. 2A). Major phylogroup A was made up of 10 minor phylogroups (V-XIII), and new minor phylogroup $\mathrm{XV}$, which contains two recent sequences, SK (KY996464) from South Korea and XM (KY933061) from China. This major phylogroup contained six Southeast Asia sequences, five



(Continued)

Fig. 2. Maximum likelihood phylograms obtained from alignment of nucleotide (nt) sequences of papaya ringspot virus (PRSV). The comparisons made were between (A) the following nonrecombinant and recombinant sequences: six from Papua New Guinea (PNG) sequenced in this study, the 17 sequenced previously from Australia and East Timor, and 37 other complete PRSV genomes from elsewhere obtained from GenBank, and (B) the following nonrecombinant sequences: the six from PNG, 15 previously published Australian and East Timorese genome sequences, and 21 other genome sequences from elsewhere obtained from GenBank. The trees were created in MEGA 7.0.14 using Clustal W with 1,000 replicates. Bootstrap values are percentages with only values over $50 \%$ shown at the nodes. The trees were rooted with zucchini tigre

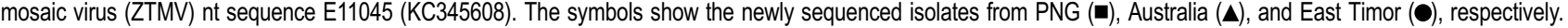


East Timorese and one Thai, and East Asian sequences from China, Korea, and Taiwan. The five sequences from East Timor all grouped together within minor phylogroup VI. The closest sequence to the East Timorese was still TW (AY010722) from Thailand in minor phylogroup V. Major phylogroup B contained isolates from Asia, Australia, Oceania, Europe, South America, and North America. It consisted of four minor phylogroups (I-IV) and new minor phylogroup XIV not reported previously by Maina et al. (2017b). The six new PNG sequences all grouped together with the 12 Australian sequences within minor phylogroup I. They clustered between sequence 16R (KX6558873) from Ayr in QLD and B9 (KX655867) from Broome in WA. Sequence TUL15 (KY039583) from Mexico was also placed in minor phylogroup I. Sequences VR (KT275937) and CH (KT275938) from Colombia in South America grouped together within new minor phylogroup XIV.

Recombination. Comparisons among the complete coding regions of the six new PRSV sequences and the 54 complete coding sequences retrieved from GenBank, revealed 26 firm recombination

Fig. 2. (Continued from previous page)

B 
events within 18 sequences. The numbers of such events within each recombinant sequence were: one in 13 sequences, two in two sequences (R3, W), and three in three sequences (XM, P, KO-WA). There were recombinant sequences in nine of the 15 minor phylogroups. However, there was no evidence of any recombination within minor phylogroups II, III, VIII, X, XII, and XIV. All PNG and Australian isolates were nonrecombinants. The sequences in major phylogroup A had 22 recombination events, whereas there were only four recombination events within major phylogroup B: these were in sequences TUL15 (KY039583) in B-I, and DEL (EF017707), HYD (KP743091), and W (EU475877) in B-IV. Overall, the 5'UTR, P1, CI, NIa-Pro, 6K2, and NIb regions contained most of the recombination breakpoints detected (Table 2). Isolates TM50 and TM32 from East Timor had firm recombination breakpoints within their P1 and/or 5'UTR regions, but the beginnings and positions of these predicted recombination breakpoints were slightly different from those reported previously for these two sequences when Maina et al. (2017b) used RDP4.7. Neither of sequences VR (KT275937) nor CH (KT275938) within new minor phylogroup XIV were recombinants. Sequences SK (KY996464) and XM (KY933061) in new minor phylogroup XV were both recombinants, and were identified as a minor parent and major parent of each other, respectively. The minor parent of $\mathrm{XM}$ is isolate $\mathrm{MexVrPo}$, from minor group II of major phylogroup B.

Upon removal of nonrecombinant genomes and constructing a recombinant-free phylogenetic tree, major phylogroups A and B remained, but minor phylogroups IV, VII, VIII, and XV were lost (Fig. 2B). When a maximum likelihood phylogenetic tree was constructed using a PRSV alignment of genomic sequences that included both nonrecombinants and recombinants from which regions with recombinationally derived tracts of sequence were removed before analysis, the tree obtained still revealed evidence of distinct phylogroups (Fig. 3). Major phylogroups A and B were present. However, within major phylogroup A, there were mergers involving seven minor phylogroups, with the following merged groups forming, V/VII/VIII, IX/X/XI, and XI/XII, associated with either decrease in phylogroup size (VII) or complete phylogroup disappearance of seven minor phylogroups (V, VIII, X, IX, XI, XII). Merged minor phylogroups IX/X/XI and XI/XII both contained sequences from the former XI phylogroup: recombinant sequence KO-WA (AB369277) appeared in IX/X/XI, but nonrecombinant sequences Ping Tong (DQ34077) and prT3-AX-M-Ph (JX448731) were both in XI/XII. Similarly, merged minor phylogroup V/VII/VIII contained a single recombinant sequence HN-DF (KT895257) from VII, in addition to recombinant sequence $\mathrm{P}$ (AY162218) from VII and nonrecombinant sequence W (AY010722) from V. Within major phylogroup B, sequence DEL (EFOI77O7) from minor phylogroup IV merged with the minor phylogroup III sequences to form merged phylogroup III/ IV, but the other two sequences from minor phylogroup IV, HYD (KP743981), and W (EU475877), were placed next to the two sequences in minor phylogroup XV within major phylogroup A.

Sequence identities. When the coding regions of the 42 nonrecombinant PRSV genomes were analyzed, sequences 17B and 22A from PNG were identical. The greatest divergence between different PNG sequences was the $96.0 \%$ nucleotide (nt) percentage identity between sequences $12 \mathrm{~B}$ and $22 \mathrm{~A}$. The closest genetic matches

Table 2. Recombination events identified by the RDP5.2 package within 60 genomes of Papaya ringspot virus

\begin{tabular}{|c|c|c|c|c|c|c|c|c|c|}
\hline \multirow[b]{2}{*}{ Events } & \multirow[b]{2}{*}{ Isolate } & \multirow[b]{2}{*}{ Phylogroup } & \multirow{2}{*}{$\begin{array}{c}\text { Detected } \\
\text { recombinant }\end{array}$} & \multirow{2}{*}{$\begin{array}{c}\text { Detected } \\
\text { breakpoint } \\
\text { position }\end{array}$} & \multirow[b]{2}{*}{ Genes affected } & \multicolumn{2}{|c|}{ Parental sequences } & \multirow{2}{*}{$\begin{array}{c}\text { Detected methods } \\
\text { in RDP5.2 }\end{array}$} & \multirow{2}{*}{$\begin{array}{c}\text { Highest } P \\
\text { value }\end{array}$} \\
\hline & & & & & & Major & Minor & & \\
\hline 1 & SK & $X V$ & KY996464 & $4,281-7,706$ & $\mathrm{CI}, 6 \mathrm{~K} 2$ & KF791028 & KY933361 & $\mathrm{R}, \mathrm{M}, \mathrm{C}, \mathrm{S}$ & $7.345 \times 10^{-60}$ \\
\hline 2 & $\mathrm{XM}$ & $\mathrm{XV}$ & KY933061 & $3,423-4,264$ & $\mathrm{P} 3,6 \mathrm{~K} 1$ & KY996464 & KF791028 & $\mathrm{R}, \mathrm{G}, \mathrm{B}, \mathrm{M}, \mathrm{C}, \mathrm{S}, \mathrm{T}$ & $8.790 \times 10^{-21}$ \\
\hline 3 & W & IV & EU475877 & $293-6,390$ & $\begin{array}{l}\text { P1, HC-Pro, P3, 6K1, CI, } \\
\text { 6K2, Vpg }\end{array}$ & KY996464 & AY231130 & $\mathrm{M}, \mathrm{C}, \mathrm{S}, \mathrm{T}$ & $5.282 \times 10^{-23}$ \\
\hline 4 & $\mathrm{XM}$ & $X V$ & KY933061 & $152-1,967$ & P1, HC-Pro & KY996464 & HQ424465 & $\mathrm{R}, \mathrm{B}, \mathrm{M}, \mathrm{C}, \mathrm{S}, \mathrm{T}$ & $8.219 \times 10^{-41}$ \\
\hline 5 & $\mathrm{XM}$ & $\mathrm{XV}$ & KY933061 & $8,906-10,396$ & $\mathrm{NIb}, \mathrm{CP}$ & KY996464 & JX448369 & $\mathrm{R}, \mathrm{B}, \mathrm{M}, \mathrm{C}, \mathrm{S}, \mathrm{T}$ & $5.374 \times 10^{-11}$ \\
\hline 6 & DEL & IV & EF017707 & $1-908$ & 5'UTR, P1 & AY231130 & AY162218 & $\mathrm{B}, \mathrm{C}, \mathrm{S}, \mathrm{T}$ & $7.803 \times 10^{-05}$ \\
\hline 7 & TUL15 & II & KY039583 & $2,205-6,694$ & $\begin{array}{l}\text { HC-Pro, P3, 6K1, CI, } \\
\text { 6K2, Vpg }\end{array}$ & KX655869 & EU126128 & $\mathrm{B}, \mathrm{M}, \mathrm{C}, \mathrm{S}, \mathrm{T}$ & $3.874 \times 10^{-07}$ \\
\hline 8 & W & $\mathrm{V}$ & EU475877 & $8,969-9,096$ & $\mathrm{NIb}, \mathrm{CP}$ & KP743981 & EF017707 & $\mathrm{R}, \mathrm{B}, \mathrm{M}, \mathrm{C}$ & $2.958 \times 10^{-45}$ \\
\hline 9 & $\mathrm{HN}-1$ & VII & HQ424465 & $4,845-10,057$ & $\begin{array}{l}\text { CI, 6K2, Vpg, NIa-Pro, } \\
\text { NIb, CP }\end{array}$ & KF791028 & KT895257 & $\mathrm{R}, \mathrm{B}, \mathrm{M}, \mathrm{C}, \mathrm{S}, \mathrm{T}$ & $4.658 \times 10^{-15}$ \\
\hline 10 & $\mathrm{HNVb}$ & VII & KF791028 & $6,231-8,639$ & 6K2, Vpg, NIa-Pro, NIb & KT633943 & X97251 & $\mathrm{R}, \mathrm{B}, \mathrm{M}, \mathrm{C}, \mathrm{S}, \mathrm{T}$ & $6.481 \times 10^{-05}$ \\
\hline 11 & $\begin{array}{l}\text { KO- } \\
\text { WA }\end{array}$ & XI & AB369277 & $563-3,759$ & P1, HC-Pro, P3 & DQ340770 & DQ340771 & $\mathrm{R}, \mathrm{G}, \mathrm{B}, \mathrm{M}, \mathrm{C}, \mathrm{S}, \mathrm{T}$ & $5.155 \times 10^{-19}$ \\
\hline 12 & $\mathrm{R} 3$ & XIII & KJ755852 & $2,535-5,218$ & HC-Pro, P3, 6K1, CI & DQ340770 & JX448372 & $\mathrm{R}, \mathrm{G}, \mathrm{B}, \mathrm{M}, \mathrm{C}, \mathrm{S}, \mathrm{T}$ & $9.728 \times 10^{-07}$ \\
\hline 13 & $\mathrm{P}$ & VII & EF183499 & $0-763$ & $5^{\prime} \mathrm{UTR}, \mathrm{P} 1$ & KF734962 & KT895257 & $\mathrm{R}, \mathrm{G}, \mathrm{B}, \mathrm{M}, \mathrm{C}, \mathrm{S}, \mathrm{T}$ & $8.828 \times 10^{-16}$ \\
\hline 14 & $\begin{array}{l}\text { Ping- } \\
\text { Tong }\end{array}$ & XIII & DQ340770 & $5,866-7,024$ & CI, 6K2, Vpg, NIa-Pro & JX448369 & DQ340771 & $\mathrm{R}, \mathrm{G}, \mathrm{B}, \mathrm{M}, \mathrm{C}, \mathrm{S}, \mathrm{T}$ & $9.567 \times 10^{-09}$ \\
\hline 15 & TM32 & VI & KX998707 & $26-830$ & 5'UTR, P1 & KX655865 & KT895257 & $\mathrm{R}, \mathrm{G}, \mathrm{B}, \mathrm{M}, \mathrm{C}$ & $8.284 \times 10^{-07}$ \\
\hline 16 & Hain & VII & KF734962 & $6,845-10,004$ & Vpg, NIa-Pro, Nib, CP & EF183499 & KT895257 & $\mathrm{R}, \mathrm{G}, \mathrm{B}, \mathrm{M}, \mathrm{C}, \mathrm{S}, \mathrm{T}$ & $6.982 \times 10^{-05}$ \\
\hline 17 & $\begin{array}{l}\text { KO- } \\
\text { WA }\end{array}$ & XI & AB369277 & $6,993-8,483$ & NIa-Pro, NIb & JX448370 & DQ340771 & $\mathrm{R}, \mathrm{G}, \mathrm{B}, \mathrm{M}, \mathrm{C}, \mathrm{S}, \mathrm{T}$ & $5.636 \times 10^{-05}$ \\
\hline 18 & LM & VII & KT633943 & $6,131-8,634$ & $\begin{array}{l}\text { 5'UTR, 6K2, Vpg, NIa- } \\
\text { Pro, NIb }\end{array}$ & JX448371 & KT895257 & $\mathrm{R}, \mathrm{B}, \mathrm{M}, \mathrm{C}, \mathrm{S}, \mathrm{T}$ & $8.931 \times 10^{-15}$ \\
\hline 19 & $\begin{array}{r}\mathrm{HN}- \\
\mathrm{DF}\end{array}$ & VII & KT895257 & $77-7,074$ & $\begin{array}{l}\text { P1, HC-Pro, P3, 6K1, CI, } \\
\text { 6K2, Vpg }\end{array}$ & KF734962 & KF791028 & $\mathrm{R}, \mathrm{B}, \mathrm{M}, \mathrm{C}, \mathrm{S}, \mathrm{T}$ & $8.905 \times 10^{-07}$ \\
\hline 20 & $\begin{array}{l}\text { KO- } \\
\text { WA }\end{array}$ & XI & AB369277 & $3,809-5,130$ & $\mathrm{P} 3,6 \mathrm{~K} 1, \mathrm{C} 1$ & JX448371 & KF791028 & $\mathrm{R}, \mathrm{B}, \mathrm{M}, \mathrm{C}, \mathrm{T}$ & $8.275 \times 10^{-05}$ \\
\hline 21 & $\mathrm{P}$ & VII & EF183499 & $4,317-5,380$ & $\mathrm{C} 1$ & KF734962 & KT633943 & $\mathrm{R}, \mathrm{B}, \mathrm{M}, \mathrm{C}, \mathrm{S}, \mathrm{T}$ & $3.422 \times 10^{-05}$ \\
\hline 22 & R3 & XIII & KJ558852 & $3,224-4,019$ & $\mathrm{P} 3,6 \mathrm{~K} 1$ & DQ340769 & DQ340771 & $\mathrm{R}, \mathrm{G}, \mathrm{M}, \mathrm{C}, \mathrm{S}$ & $7.498 \times 10^{-04}$ \\
\hline 23 & P-5-19 & IX & EU882728 & $115-2,027$ & 5'UTR, P1, HC-Pro & JX448371 & X97251 & $\mathrm{R}, \mathrm{B}, \mathrm{M}, \mathrm{C}, \mathrm{S}$ & $9.930 \times 10^{-12}$ \\
\hline 24 & TM50 & VI & KX655874 & $962-1,336$ & $\mathrm{P} 1$ & KX655863 & AY010722 & $\mathrm{R}, \mathrm{G}, \mathrm{B}, \mathrm{M}, \mathrm{C}, \mathrm{S}, \mathrm{T}$ & $9.817 \times 10^{-13}$ \\
\hline 25 & HYD & IV & KP743981 & $331-9,099$ & $\begin{array}{l}\text { P1, HC-Pro, P3, 6K1, CI, } \\
\text { 6K2, Vpg, CP }\end{array}$ & KX655860 & X67673 & $\mathrm{R}, \mathrm{M}, \mathrm{C}, \mathrm{S}$ & $4.526 \times 10^{-04}$ \\
\hline 26 & $\mathrm{P}$ & VII & EF183499 & $9,480-10,391$ & $\mathrm{CP}, 3^{\prime} \mathrm{UTR}$ & KF734962 & KF791028 & $\mathrm{R}, \mathrm{G}, \mathrm{B}, \mathrm{M}, \mathrm{C}, \mathrm{S}, \mathrm{T}$ & $6.615 \times 10^{-15}$ \\
\hline
\end{tabular}

${ }^{\mathrm{a}}$ RDP 5.2 methods: $\mathrm{B}=$ Bootscan, $\mathrm{C}=$ Chimera, $\mathrm{G}=$ Gencov; $\mathrm{M}=$ Maxchi, $\mathrm{S}=$ Siscan, $\mathrm{R}=\mathrm{RDP}, \mathrm{T}=$ Topal. 
between PNG and Australian sequences within minor phylogroup B-I were the $96.8 \%$ and $96.9 \%$ nt identities between B9 (KX655867) from Broome, WA and PNG sequences 16A and 12B, respectively. There was also a $96.2 \%$ nt identity between sequence 16R (KX655873) from Ayr, QLD, and both 16A and 12B from PNG. However, sequence 16R came from the closest Australian sampling site to PNG, whereas B9 was from the most remote site. The closest nt identity between a PNG sequence and a non-Australian sequence was $92.1 \%$ between sequence 16A and sequence Mex-VrPO AY231130 in phylogroup B-II. The closest genetic match between East Timorese and PNG sequences was the $83.1 \%$ nt identity between TM4 (KX655864) with both 12B and $16 \mathrm{~A}$.

\section{Discussion}

This paper describes the first complete PRSV genome sequences from infected cucurbit crops growing in PNG or anywhere else in Oceania apart from Australia, and demonstrates genetic connectivity between PNG and northern Australian PRSV populations. Evidence for genetic connectivity comes from the genetic match between genomic sequences from both countries and phylogenetic placement of all six PNG isolates within a minor phylogroup that otherwise contains only 12 northern Australian genomic sequences and a single recombinant from the United States. The PNG sequences came from the country's Eastern and Western Highlands, and the Australian sequences were from three widely dispersed locations spanning the north of the continent. In contrast, PRSV populations from the nearby country of East Timor lacked genetic connectivity with those from either PNG or Australia. Such genomic connectivity between PRSV populations is consistent with the hypothesis that "viral pathogens of important crops are arriving in tropical Australia by crossing the sea separating it from its northern neighbors". Recombination analysis undertaken with the 60 PRSV genomes available predicted 26 recombination events, but evidence of recombination was lacking among all isolates from PNG or Australia. In a recombinant-free phylogenetic tree, the two major phylogroups remained, but four minor phylogroups were lost. Also, when the nonrecombinant data within recombinant sequences were aligned with the nonrecombinant sequences, those in seven of the previous minor phylogroups within major phylogroup A and two in major phylogroup B merged either partially or completely forming four merged minor phylogroups. The absence of detectable recombination within PNG and northern Australian PRSV isolates and the genetic connectivity between them suggest that, should they prove more virulent than those already present, isolates from East Timor, rather than ones from PNG, might pose a biosecurity threat to northern Australian agriculture.

Maina et al. (2017b) suggested only one PRSV introduction, or multiple introductions of very similar isolates, has occurred from an unknown location to Australia since agriculture commenced following the arrival of European colonists 230 years ago. It now appears that PRSV in both Australia and PNG are derived from the same single introduction or from a limited number of introductions of similar isolates. Given Australia's much briefer association with agriculture than PNG's (see the introduction), the genetic connectivity findings from our study indicate Australia's PRSV population



\section{Recombinant region}

Non-recombinant region

Major phylogroup border line

Fig. 3. Maximum likelihood phylogenetic tree obtained from alignment of nucleotides (nt) of 60 papaya ringspot virus genomes with recombinant regions removed. The tree was inferred using PHYML/RAxML/FastTREE with 1,000 bootstrap test support, model GTR-CAT and Faster RAxML tree search strategy in the RDP5.2 program, ( ) = recombinant region and $(\mathbf{G})=$ nonrecombinant region . 
might have come from PNG rather than the reverse. However, the alternative scenario of first arrival in Australia from somewhere distant followed by redistribution to PNG via human or natural movements is also plausible. This contrasts with the related cucurbit-infecting virus ZYMV where genomic sequence analysis suggested at least three separate introductions to Australia. One of these demonstrated genetic connectivity between ZYMV sequences from a northern neighbor, in this case East Timor, and a single location in northwest Australia. It also contrasts with SPFMV infecting sweetpotato where genomic sequence analysis suggested at least two separate introductions to Australia and, for one of these introductions, genetic connectivity was demonstrated between sequences from two widely separated northern Australian locations and East Timorese sequences (see the introduction). In the prehistoric era, Australia and New Guinea formed a single landmass connected by an extensive land bridge. The last part of this land bridge which linked PNG across the Torres Strait to the Cape York Peninsula in northeast Australia became flooded about 6,000 years ago, leaving a string of islands between the two countries (Reeves et al. 2008; Voris 2000). Pathways of virus introduction that do not involve trade or land borders but are likely to apply to an island continent like Australia include (i) viruliferous insect vectors blown by monsoonal winds, (ii) infected cucurbit seeds carried in the guts of migrating birds, or (iii) fishermen from nearby countries inadvertently discarding virus-infected fruits while briefly landing along the coastline away from ports (Gibbs et al. 2010; Lecoq et al. 2003; Maina et al. 2017a,b). Evidence of wind-borne insect vectors blown from PNG, East Timor, or Indonesia bringing viruses into northern Australia is available, e.g., for Japanese encephalitis virus and bluetongue virus carried by viruliferous mosquitos or biting mites (Johansen et al. 2001, 2003; Eagles et al. 2013). Moreover, virus introductions into northern Australia seem likely to grow in the future as the intensity of monsoonal winds increases due to climate change (Jones 2009, 2016; Jones and Barbetti 2012). Indirect evidence that this pathway might have occurred with aphid-borne PRSV is provided by the genetic connectivity found between PRSV populations in PNG and northern Australia, including Ayr in northeast QLD close to the Cape York Peninsula. Direct evidence of this would require testing flying aphid vectors caught while being blown across the Torres Strait.

Recombination provides a means by which viruses invade new hosts or develop greater pathogenicity and/or virulence (Chare and Holmes 2006; Gibbs and Ohshima 2010; Gibbs et al. 2008b; James et al. 2016; Jones 2009; Kehoe et al. 2014b; Lai 1992; Maina et al. 2018c; Revers et al. 1996; Valli et al. 2007). Using the RDP4.7 recombination analysis package, Maina et al. (2017b) found 13 recombination events among the 49 complete PRSV genomes then available. The 10 recombinant genomes detected included two from East Timor and eight from geographically more remote countries, but none from Australia. Most recombination events occurred in the P1 region. In the current study, we used the most recent recombination package (RDP5.2) to search for recombinants among the 60 PRSV genomes now available. This revealed eight additional recombinant PRSV isolates and 16 more firm recombination events. None of these recombinants were from PNG, but as found previously (Maina et al. 2017b), two were East Timorese while none were Australian. Only four of the 26 recombinants found were in major phylogroup B which included isolates from five continents, in contrast to major phylogroup A which contained isolates solely from Asia, 22 of which were recombinants. Moreover, when the same individual genomes were analyzed by both packages, more recombination events were sometimes found by RDP5.2, e.g., two instead of one firm recombination event in isolate R-3 and three instead of one such event in isolate P. In addition, RDP5.2 commonly detected recombination breakpoints not only within the $\mathrm{P} 1$ region, as reported previously by Maina et al. (2017b) using RDP4.7, but also in PRSV's CI, NIa-Pro, NIb, 6K2, and 5'UTR regions. Similarly, when Maina et al. (2018c) studied recombination in the potyviruses SPFMV and SPVC using RDP5.2, they found a high frequency of recombination breakpoints not only within the P1 region, but also in their NIa$\mathrm{Pro}, \mathrm{NIb}$, and $\mathrm{CP}$ regions. In contrast, in addition to in their PI region, studies with other potyviruses found recombination breakpoints most frequently in their CI and VPg regions (Desbiez and Lecoq 2008; Ohshima et al. 2007; Tan et al. 2004).

Recombination causes challenges when the evolutionary relationships of virus genomic sequences are being studied and its complicating influences on phylogenetic analyses are well known (Chare and Holmes 2006; Myrta et al. 2001; Salminen 2003). However, it can be accounted for by excluding recombinant genomes or removing recombinationally derived tracts of sequence from recombinant genomes prior to analysis (Chikh-Ali et al. 2016; Cuevas et al. 2012; Gibbs et al. 2017; Karasev et al. 2011; Maina et al. 2018c; Moury 2010; Ogawa et al. 2012; Visser et al. 2012; Santillan et al. 2018). Moreover, when few complete genomes are available, it may be undesirable to discard data while selecting recombination-free datasets. In this study, we produced phylogenetic trees containing all PRSV sequences by including the recombined sequences without their recombinationally derived tracts. When this was done, nine of the previous 15 minor phylogroups merged partially or completely to form the merged groups III/VI, V/VII/VIII, IX/X/XI, and XI/XII. In addition, two of the recombinants from major phylogroup B's minor phylogroup IV moved close to minor phylogroup XV in major phylogroup A. Because of the recent advent of agriculture, the Australian continent is still free of many damaging viral pathogens or their virulent strains (see introduction). Moreover, climate change is projected to cause increasing annual monsoonal winds potentially carrying insect virus vectors to the north of the continent (see above, in Discussion). The genetic connectivity between northern Australian and PNG isolates suggests that PRSV isolates from East Timor, rather than PNG, might pose a biosecurity threat to northern Australian agriculture should they prove more virulent than those already present. These findings along with the previously reported genetic connectivity among East Timorese and localized northern Australian populations of ZYMV and SPFMV (Maina et al. 2017a,b, 2018a,c) emphasize the need for increased biosecurity measures in northern Australia. Such measures include enhanced viral pathogen surveillance activities and increased preparedness for containing or eradicating new virus incursions.

\section{Acknowledgments}

This study forms part of a Ph.D. project by the first author at the University of Western Australia (UWA). We thank Darren Martin for advice over recombination analysis using the RDP5.2 package, Kila Waiyo for help with the map in Fig. 1A, and Mingpei You of the School of Agriculture and Environment, UWA for administrative support.

\section{Literature Cited}

Altschul, S. F., Gish, W., Miller, W., Myers, E. W., and Lipman, D. J. 1990. Basic local alignment search tool. J. Mol. Biol. 215:403-410.

Bao, Y., Chetvernin, V., and Tatusova, T. 2014. Improvements to pairwise sequence comparison (PASC): A genome-based web tool for virus classification. Arch. Virol. 159:3293-3304.

Bateson, M. F., and Dale, J. L. 1992. The nucleotide sequence of the coat protein gene and 3' untranslated region of papaya ringspot virus type W (Aust). Arch. Virol. 123:101-109.

Bateson, M. F., Henderson, J., Chaleeprom, W., Gibbs, A. J., and Dale, J. L. 1994 Papaya ringspot potyvirus: Isolate variability and the origin of PRSV type P (Australia). J. Gen. Virol. 75:3547-3553.

Bateson, M. F., Lines, R. E., Revill, P., Chaleeprom, W., Ha, C. V., Gibbs, A. J., and Dale, J. L. 2002. On the evolution and molecular epidemiology of the potyvirus Papaya ringspot virus. J. Gen. Virol. 83:2575-2585.

Bayot, R. G., Villegas, V. N., Magdalita, P. M., Jovellana, M. D., Espino, T. M., and Exconde, S. B. 1990. Seed transmissibility of papaya ringspot virus. Philipp. J. Crop Sci. 15:107-111.

Büchen-Osmond, C., Crabtree, K., Gibbs, A., and Mclean, G. 1988. Viruses of plants in Australia. Descriptions and lists from the VIDE database. Australian National University, Canberra, Australia.

CABI/EPPO. 2013. Papaya ringspot virus. Distribution Maps of Plant Diseases, No. 902. CAB International, Wallingford, UK.

Chare, E. R., and Holmes, E. C. 2006. A phylogenetic survey of recombination frequency in plant RNA viruses. Arch. Virol. 151:933-946.

Chikh-Ali, M., Vander Pol, D., Nikolaeva, O. V., Melzer, M. J., and Karasev, A. V. 2016. Biological and molecular characterization of a tomato isolate of Potato virus $Y$ (PVY) of the PVYC lineage. Arch. Virol. 161:3561-3566.

Chin, M., Ahmad, M. H., and Tennant, P. 2007. Momordica charantia is a weed host reservoir for Papaya ringspot virus type P in Jamaica. Plant Dis. 91:1518. 
Coutts, B. A., and Jones, R. A. C. 2005. Incidence and distribution of viruses infecting cucurbit crops in the Northern Territory and Western Australia. Aust. J. Agric. Res. 56:847-858.

Coutts, B. A., Kehoe, M. A., and Jones, R. A. C. 2011a. Minimising losses caused by Zucchini yellow mosaic virus in vegetable cucurbit crops in tropical, subtropical and Mediterranean environments through cultural methods and host resistance. Virus Res. 159:141-160.

Coutts, B. A., Kehoe, M. A., Webster, C. G., Wylie, S. J., and Jones, R. A. C. 2011 b. Zucchini yellow mosaic virus: Biological properties, detection procedures and comparison of coat protein gene sequences. Arch. Virol. 156:2119-2131.

Cuevas, J. M., Delaunay, A., Visser, J. C., Bellstedt, D. U., Jacquot, E., and Elena, S. F. 2012. Phylogeography and molecular evolution of Potato virus Y. PLoS One 7:e37853.

Davis, R. I., Thomas, J. E., McMichael, L. A., Dietzgen, R. G., Callaghan, B., James, A. P., Gunua, T. G., and Rahamma, S. 2002. Plant virus surveys on the island of New Guinea and adjacent regions of northern Australia. Australas. Plant Pathol. 31:385-390.

Denham, T. P., Haberle, S. G., Lentfer, C., Fullagar, R., Field, J., Therin, M., Porch, N., and Winsborough, B. 2003. Origins of agriculture at Kuk Swamp in the highlands of New Guinea. Science 301:189-193.

Desbiez, C., and Lecoq, H. 2008. Evidence for multiple intraspecific recombinants in natural populations of Watermelon mosaic virus (WMV, potyvirus). Arch. Virol. 153:1749-1754.

Desbiez, C., Wipf-Scheibel, C., Millot, P., Verdin, E., Dafalla, G., and Lecoq, H. 2017. New species in the papaya ringspot virus cluster: Insights into the evolution of the PRSV lineage. Virus Res. 241:88-94.

Eagles, D., Walker, P. J., Zalucki, M. P., and Durr, P. A. 2013. Modelling spatiotemporal patterns of long-distance Culicoides dispersal into northern Australia. Prev. Vet. Med. 110:312-322.

Gibbs, A., and Ohshima, K. 2010. Potyviruses and the digital revolution. Annu. Rev. Phytopathol. 48:205-223.

Gibbs, A. J., Fargette, D., Garcia-Arenal, F., and Gibbs, M. J. 2010. Time-the emerging dimension of plant virus studies. J. Gen. Virol. 91:13-22.

Gibbs, A. J., Mackenzie, A. M., Wei, K., and Gibbs, M. J. 2008a. The potyviruses of Australia. Arch. Virol. 153:1411-1420.

Gibbs, A. J., Ohshima, K., Phillips, M. J., and Gibbs, M. J. 2008b. The prehistory of Potyviruses: Their Initial radiation was during the dawn of agriculture. PLoS One $3: \mathrm{e} 2523$.

Gibbs, A. J., Ohshima, K., Yasaka, R., Mohammadi, M., Gibbs, M. J., and Jones, R. A. C. 2017. The phylogenetics of the global population of Potato virus $Y$ and its necrogenic recombinants. Virus Evol. 23:vex002.

Gibbs, M. J., Armstrong, J. S., and Gibbs, A. J. 2000. Sister-scanning: A Monte Carlo procedure for assessing signals in recombinant sequences. Bioinformatics 16:573-582.

Greber, R. S. 1969. Viruses infecting cucurbits in Queensland. Queensl. J. Agric. Anim. Sci. 26:145-171.

Guerret, M. G. L., Nyalugwe, E. P., Maina, S., Barbetti, M. J., van Leur, A. G. J., and Jones, R. A. C. 2017. Biological and molecular properties of a Turnip mosaic virus (TuMV) strain that breaks TuMV resistances in Brassica napus. Plant Dis. 101:674-683.

Herrington, M. E. 1987. Yield and quality of increase with delayed infection by Papaya ringspot virus type W. Queensland J. Agric. Anim. Sci. 44:117-121.

James, D., Sanderson, D., Varga, A., Sheveleva, A., and Chirkov, S. 2016 Genome sequence analysis of new isolates of the Winona strain of Plum pox virus and the first definitive evidence of intrastrain recombination events. Phytopathology 106:407-416.

Johansen, C. A., Farrow, R., Morrisen, A., Mackenzie, J. S., and Ritchie, S. A. 2001. Windborne mosquitoes: Could they be a mechanism of incursions of Japanese encephalitis virus into Australia? Arbovirus Res. Aust. 8:180-186.

Johansen, C. A., Farrow, R. A., Morrisen, A., Bellis, G., van den Hurk, A. F., Montgomery, B., Mackenzie, J. S., and Ritchie, S. A. 2003. Collection of wind-borne haematophagous insects in the Torres Strait, Australia. Med. Vet. Entomol. 17:102-111.

Jones, R. A. C. 1996. Report on survey for virus diseases in crops in the Ord River Irrigation Area. Department of Agriculture Western Australia, Perth, Australia.

Jones, R. A. C. 2009. Plant virus emergence and evolution: Origins, new encounter scenarios, factors driving emergence, effects of changing world conditions, and prospects for control. Virus Res. 141:113-130.

Jones, R. A. C. 2016. Future scenarios for plant virus pathogens as climate change progresses. Adv. Virus Res. 95:87-147.

Jones, R. A. C., and Barbetti, M. J. 2012. Influence of climate change on plant disease infections and epidemics caused by viruses and bacteria. CAB Reviews 7, No. 22, pp. 1-32. https://www.cabi.org/cabreviews.

Jones, R. A. C., and Kehoe, M. A. 2016. A proposal to rationalize within-species plant virus nomenclature: Benefits and implications of inaction. Arch. Virol. 161:2051-2057.

Karasev, A. V., Hu, X., Brown, C. J., Kerlan, C., Nikolaeva, O. V., Crosslin, J. M., and Gray, S. M. 2011. Genetic diversity of the ordinary strain of Potato virus $Y$ (PVY) and origin of recombinant PVY strains. Phytopathology 101:778-785.

Katoh, K., Misawa, K., Kuma, K.-I., and Miyata, T. 2002. MAFFT: A novel method for rapid multiple sequence alignment based on fast Fourier transform. Nucleic Acids Res. 30:3059-3066.

Kearse, M., Moir, R., Wilson, A., Stones-Havas, S., Cheung, M., Sturrock, S., Buxton, S., Cooper, A., Markowitz, S., Duran, C., Thierer, T., Ashton, B.,
Meintjes, P., and Drummond, A. 2012. Geneious basic: An integrated and extendable desktop software platform for the organization and analysis of sequence data. Bioinformatics 28:1647-1649.

Kehoe, M. A., Coutts, B. A., Buirchell, B. J., and Jones, R. A. C. 2014a. Plan virology and next generation sequencing: Experiences with a Potyvirus. PLoS One 9:e104580.

Kehoe, M. A., Coutts, B. A., Buirchell, B., and Jones, R. A. C. 2014b. Split personality of a potyvirus: To specialize or not to specialize. PLoS One 9:e105770.

Kumar, S., Stecher, G., and Tamura, K. 2016. MEGA7: Molecular evolutionary genetics analysis version 7.0 for bigger datasets. Mol. Biol. Evol. 33:1870-1874.

Lai, M. M. 1992. RNA recombination in animal and plant viruses. Microbiol. Rev. $56: 61-79$

Larkin, M. A., Blackshields, G., Brown, N. P., Chenna, R., McGettigan, P. A., McWilliam, H., Valentin, F., Wallace, I. M., Wilm, A., Lopez, R., and Thompson, J. D. 2007. Clustal W and Clustal X version 2.0. Bioinformatics 23:2947-2948

Lecoq, H., Desbiez, C., Wipf-Scheibel, C., and Girard, M. 2003. Potential involvement of melon fruit in the long distance dissemination of cucurbit potyviruses. Plant Dis. 87:955-959.

Magdalita, P. M., Bayot, R. G., and Villegas, V. N. 1990. Diplocyclos palmatus L. Jeffrey: A new weed host of papaya ringspot virus. Philipp. J. Crop Sci. 15 163-168.

Maina, S., Barbetti, M. J., Edwards, O., de Almeida, L., Ximenes, A., and Jones, R. A. C. 2018a. Sweet potato feathery mottle virus and Sweet potato virus $C$ from East Timorese and Australian sweetpotato: Biological and molecular properties, and biosecurity implications. Plant Dis. 102:589-599.

Maina, S., Barbetti, M. J., Edwards, O. R., Minemba, D., Areke, M. W., and Jones, R. A. C. 2018b. First complete genome sequence of Cucurbit aphid-borne yellows virus from Papua New Guinea. Genome Announc. 6:e00162-e18.

Maina, S., Barbetti, M. J., Martin, D. P., Edwards, O. R., and Jones, R. A. C. 2018c New isolates of Sweet potato feathery mottle virus and Sweet potato virus $C$ : Biological and molecular properties, and recombination analysis based on complete genomes. Plant Dis. 102:1899-1914.

Maina, S., Coutts, B. A., Edwards, O. R., de Almeida, L., Kehoe, M. A., Ximenes, A., and Jones, R. A. C. 2017a. Zucchini yellow mosaic virus populations from East Timorese and northern Australian cucurbit crops: molecular properties, genetic connectivity and biosecurity implications. Plant Dis. 101:1236-1245.

Maina, S., Coutts, B. A., Edwards, O. R., de Almeida, L., Ximenes, A., and Jones, R. A. C. 2017b. Papaya ringspot virus populations from East Timorese and northern Australian cucurbit crops: Biological and molecular properties, and absence of genetic connectivity. Plant Dis. 101:985-993.

Maina, S., Edwards, O. R., Barbetti, M. J., de Almeida, L., Ximenes, A., and Jones, R. A. C. 2016a. Deep sequencing reveals complete genome of Sweet potato virus $G$ from East Timor. Genome Announc. 4:e00957-16.

Maina, S., Edwards, O. R., de Almeida, L., Ximenes, A., and Jones, R. A. C. 2016b. Complete genome sequences of the Carlavirus Sweet potato chlorotic fleck virus from East Timor and Australia. Genome Announc. 4:e0414-16.

Maina, S., Edwards, O. R., de Almeida, L., Ximenes, A., and Jones, R. A. C 2016c. Complete genome sequences of the Potyvirus Sweet potato virus 2 from East Timor and Australia. Genome Announc. 4:e00504-16.

Maina, S., Edwards, O. R., de Almeida, L., Ximenes, A., and Jones, R. A. C. 2016d. First complete genome sequence of Suakwa aphid-borne yellows virus from East Timor. Genome Announc. 4:e00718-16.

Maina, S., Edwards, O. R., de Almeida, L., Ximenes, A., and Jones, R. A. C 2016e. First complete genome sequence of Bean common mosaic necrosis virus from East Timor. Genome Announc. 4:e01049-16.

Maina, S, Edwards, O. R., de Almeida, L., Ximenes, A., and Jones, R. A. C. 2017c Metagenomic analysis of cucumber RNA from East Timor reveals an Aphid lethal paralysis virus genome. Genome Announc. 5:e01445-16.

Maina, S., Edwards, O. R., de Almeida, L., Ximenes, A., and Jones, R. A. C. 2017d. RNA-seq strand specific library from East Timorese cucumber sample reveals complete Cucurbit aphid-borne yellows virus genome. Genome Announc. 5:e0320-17.

Maina, S., Edwards, O. R., de Almeida, L., Ximenes, A., and Jones, R. A. C 2017e. First complete Squash leaf curl China virus genomic segment DNAA sequence from East Timor. Genome Announc. 5:e00483-17.

Maina, S., Edwards, O. R., and Jones, R. A. C. 2016f. First complete genome sequence of Pepper vein yellows virus from Australia. Genome Announc. 4: e00450-16.

Maina, S., Edwards, O. R., and Jones, R. A. C. 2017f. Two complete genome sequences of Squash mosaic virus from 20-year-old cucurbit leaf samples from Australia. Genome Announc. 5:e00778-17.

Maina, S., and Jones, R. A. C. 2017. Analysis of an RNA-seq strand-specific library sample reveals a complete genome of Hardenbergia mosaic virus from native wisteria, an indigenous virus from Southwest Australia. Genome Announc. 5:e0599-17.

Mansilla, P. J., Moreira, A. G., Mello, A. P. O. A., Rezende, J. A. M., Ventura, J. A., Yuki, V. A., and Levatti, F. J. 2013. Importance of cucurbits in the epidemiology of Papaya ringspot virus type P. Plant Pathol. 62:571-577.

Martin, D., Williamson, C., and Posada, D. 2005. RDP2: Recombination detection and analysis from sequence alignment. Bioinformatics 21:260-262.

Martin, D. P., Murrell, B., Golden, M., Khoosal, A., and Muhire, B. 2015. RDP4 Detection and analysis of recombination patterns in virus genomes. Virus Evol 1:vev003. 
McGuire, G., and Wright, F. 2000. TOPAL 2.0: Improved detection of mosaic sequences within multiple alignments. Bioinformatics 16:130-134.

Moury, B. 2010. A new lineage sheds light on the evolutionary history of Potato virus $Y$. Mol. Plant Pathol. 11:161-168.

Muhire, B. M., Varsani, A., and Martin, D. P. 2014. SDT: A virus classification tool based on pairwise sequence alignment and identity calculation. PLoS One 9:e108277.

Myrta, A., Boscia, D., Potere, O., Kölber, M., Németh, M., Di Terlizzi, B., Cambra, M., and Savino, V. 2001. Existence of two serological subclusters of Plum pox virus, strain M. Eur. J. Plant Pathol. 107:845-848.

Ndunguru, J., Taylor, N. J., Yadav, J., Aly, H., Legg, J. P., Aveling, T., Thompson, G., and Fauquet, C. M. 2005. Application of FTA technology for sampling, recovery and molecular characterization of viral pathogens and virus-derived transgenes from plant tissues. Virol. J. 2:45.

Ogawa, T., Nakagawa, A., Hataya, T., and Ohshima, K. 2012. The genetic structure of populations of Potato virus $Y$ in Japan; based on the analysis of 20 full genomic sequences. J. Phytopathol. 160:661-673.

Ohshima, K., Tomitaka, Y., Wood, J. T., Minematsu, Y., Kajiyama, H., Tomimura, K., and Gibbs, A. J. 2007. Patterns of recombination in Turnip mosaic virus genomic sequences indicate hotspots of recombination. J. Gen. Virol. 88:298-315.

Ohshima, K., Yamaguchi, Y., Hirota, R., Hamamoto, T., Tomimura, K., Tan, Z., Sano, T., Azuhata, F., Walsh, J. A., Fletcher, J., Chen, J., Gera, A., and Gibbs, A. 2002. Molecular evolution of Turnip mosaic virus: Evidence of host adaptation, genetic recombination and geographical spread. J. Gen. Virol. 83: 1511-1521.

Olarte Castillo, O. X. A., Fermin, G., Tabima, J., Rojas, Y., Tennant, P. F., Fuchs, M., Sierra, R., Bernal, A. J., and Restrepo, S. 2011. Phylogeography and molecular epidemiology of Papaya ringspot virus. Virus Res. 159:132-140.

Padidam, M., Sawyer, S., and Fauquet, C. M. 1999. Possible emergence of new geminiviruses by frequent recombination. Virology 265:218-225.

Posada, D., and Crandall, K. A. 2001. Evaluation of methods for detecting recombination from DNA sequences: Computer simulations. Proc. Natl. Acad. Sci. USA 98:13757-13762.

Purcifull, D., Edwardson, J., Hiebert, E., and Gonsalves, D. 1984. Papaya ringspot virus. CMI/AAB Descriptions of Plant Viruses, No. 84. CAB International, Wallingford, UK.
Rai, I. G., Temaja, M., Sudiarta, I. P., and Darmiati, N. N. 2015. Papaya ringspot virus (PRSV) causing ringspot disease on papaya in Bali. J. Biol. Agric. Healthcare 5:50-55.

Reeves, J. M., Chivas, A. R., Garcia, A., Holt, S., Couapel, M. J. J., Jones, B. G., Cendon, D. I., and Fink, D. 2008. The sedimentary record of palaeoenvironments and sea-level change in the Gulf of Carpentaria, Australia, through the last glacial cycle. Quat. Int. 183:3-22.

Revers, F., Le Gall, O., Candresse, T., Le Romancer, M., and Dunez, J. 1996. Frequent occurrence of recombinant potyvirus isolates. J. Gen. Virol. 77:1953-1965.

Salminen, M. 2003. Pages 348-377 in: Detecting recombination in viral sequences. The phylogenetic handbook - a practical approach to DNA and protein phylogeny. Cambridge University Press, Cambridge, United Kingdom.

Santillan, F. W., Fribourg, C. E., Adams, I. P., Gibbs, A. J., Boonham, N., Kehoe, M A., Maina, S., and Jones, R. A. C. 2018. The biology and phylogenetics of Potato virus $S$ isolates from the Andean Region of South America. Plant Dis. 102:869-885.

Smith, J. M. 1992. Analyzing the mosaic structure of genes. J. Mol. Evol. 34: 126-129.

Somowiyarjo, S. 1993. Detection and identification of cucurbit viruses in Yogyakarta. Ilmu Pertan. 5:657-664

Tan, Z., Wada, Y., Chen, J., and Ohshima, K. 2004. Inter- and intra-lineage recombinants are common in natural populations of Turnip mosaic virus. J. Gen. Virol. 85:2683-2696.

Thomas, J. E., and Dodman, R. L. 1993. The first record of papaya ringspot virustype P from Australia. Australas. Plant Pathol. 22:2-7.

Valli, A., Lopez-Moya, J. J., and Garcia, J. A. 2007. Recombination and gene duplication in the evolutionary diversification of P1 proteins in the family Potyviridae. J. Gen. Virol. 88:1016-1028.

Visser, J. C., Bellstedt, D. U., and Pirie, M. D. 2012. The recent recombinant evolution of a major crop pathogen Potato virus Y. PLoS One 7:e50631.

Voris, H. K. 2000. Maps of Pleistocene sea levels in Southeast Asia: Shorelines, river systems and time durations. J. Biogeogr. 27:1153-1167.

Webster, C. G. 2008. Characterisation of Hardenbergia mosaic virus and development of microarrays for detecting viruses in plants. Ph.D. thesis. Murdoch University, Perth, Australia

Zitter, T. A., Hopkins, D. L., Claude, E., and Thomas, C. E., eds. 1996 Compendium of Cucurbit Diseases. American Phytopathological Society, St. Paul, MN. 